\title{
ANALISIS KEMAMPUAN DALAM PENGEMBANGAN FILM PEMBELAJARAN MAHASISWA PENDIDIKAN FISIKA UIN WALISONGO
}

\author{
Edi Daenuri Anwar ${ }^{1}$ \\ ${ }^{1}$ Prodi Pendidikan Fisika, UIN Walisongo Semarang
}

\begin{abstract}
Research has been conducted on the development of learning film by physics teacher candidate students in learning media courses. In this research, students make a learning film about basic physics practice in accompanied by lecturer of media courses. The product of the learning film that has been created by the student is tested by the student's users.Assessment results include, sound, music and visualization. From the assessment results are processed by quantitative approach and described by the results of these quantitative processing. The results show that in general subject matter consisting of a) the suitability of the subject matter with the goals formulated, b) the subject matter is easily understood, c) the subject matter corresponds to the level of the user / student ability, d) the subject matter is presented from simple to complex, and e) the subject matter delivered coherently and regularly. The five components that users say are good. While the second element of the narrative includes a) volume, b) sound intonation to facilitate understanding, c) the style of language used is very clear, d) clarity of speech and e) the language used is simple and easy to understand. Generally good except on the component d) clarity of speech that gives sufficient appraisal. and the third assessment component of music consisting of a) music illustration supporting the program and b) music illustrations and sound effects are not too intrusive, these two elements are in enough categories.
\end{abstract}

Keywords: film, learning, physics education

\begin{abstract}
Abstrak
Telah dilakukan penelitian tentang analisa pengembangan film pembelajaran oleh mahasiswa calon guru fisika pada matakuliah media pembelajaran. Dalam penelitian ini mahasiswa membuat film pembelajaran tentang praktikum fisika Dasar di dampingi oleh dosen matakuliah media. Produk dari film pembelajaran yang telah di buat oleh mahasiswa di uji dengan oleh mahasiswa pengguna. Hasil penilaian meliputi, suara, musik dan visualisasi. Dari hasil penilaian diolah dengan pendekatan kuantitatif dan didiskripsikan berdasarkan hasil pengolahan kuantitatif tersebut. Hasilnya menunjukkan bahwa secara umum pokok materi terdiri dari a) Kesesuaian materi dengan tujuan yang dirumuskan, b) materi mudah difahami, c) materi sesuai dengan tingkat kemampuan pengguna/ Mahasiswa, d) bahan disajikan dari sederhana menuju ke kompleks, dan e) bahan yang disampaikan runtut dan teratur. Kelima komponen yang dari pengguna menyatakan baik. Sedangkan unsur kedua narasi yang meliputi a) volume suara, b) intonasi suara untuk memudahkan pemahaman, c) gaya bahasa yang digunakan sangat jelas, d) kejelasan ucapan dan e) bahasa yang digunakan sederhana dan mudah difahami. Secara umum baik kecuali pada komponen d) kejelasan ucapan yang memberikan penilain cukup. dan Komponen penilaian ketiga yaitu musik yang terdiri dari a) ilustrasi musik mendukung program dan b) ilustrasi musik dan efek suara tidak terlalu mengganggu, kedua unsur ini dalam kategori cukup.
\end{abstract}

Kata kunci : film, pembelajaran, pendidikan fisika 


\section{PENDAHULUAN}

Media pembelajaran memiliki peranan yang sangat penting dalam proses pembelajaran. Penggunaan media pendidikan, dapat membantu dosen/guru dalam menyampaikan konten materi pembelajaran. Proses pembelajaran ditentukan oleh dua komponen yaitu strategi pembelajaran yang diterapkan dan media pembelajaran yang digunakan. Kedua komponen tersebut saling berkaitan, pemilihan salah satu strategi pembelajaran mempunyai konsekuensi pada pemilihan jenis media.

Fungsi media dalam proses belajar mengajar yaitu untuk meningkatkan rangsangan peserta didik dalam kegiatan belajar. Ali, M (2005) menyatakan bahwa penggunaan media pembelajaran berbantuan komputer mempunyai pengaruh yang signifikan terhadap daya tarik siswa untuk mempelajari kompetensi yang diajarkan. Penggunaan media pembelajaran dapat menghemat waktu persiapan mengajar, meningkatkan motivasi belajar mahasiswa, dan mengurangi kesalahpahaman mahasiswa terhadap penjelasan yang diberikan dosen/Guru.

Untuk meningkatkan proses dan output hasil pembelajaran maka kemampuan untuk mendesain media adalah sebuah keniscayaan. Kemampuan mahasiswa sebagai calon Guru dalam mendesain media adalah bekal utama yang harus dijadikan standar terhadap proses pembelajaran di masa yang akan datang.

Pentingnya media berbasis komputer dalam pembelajaran sebagai media pembelajaran yang meningkatkan daya tarik siswa sementara ini tidak di imbangi dengan kemampuan guru untuk mendesain, mengolah dan memproduksinya. Sehingga yang terjadi dilapangan adalah kebanyakan guru membeli media atau mendownload dari internet baik berbayar maupun free. Sisi lain dari mendownload dari internet adalah kesulitan mengubah konten pembelajaran sehingga konten pembelajaran selalu mengikuti dengan media yang ada. Sehingga proses pembelajaran kurang eksplorasi karena tidak sesuai dengan keadaan geografis dan tingkat pemahaman siswa. Sedangkan ketika tidak ada film dengan konten yang cocok baik download yang dibutuhkan maka guru mengajarkan dengan segala keterbatasannya.

Permasalahan-permasalahan tersebut perlu adanya solusi yang strategis tentang upaya pemahaman kepada mahasiswa sebagai calon guru untuk mampu meningkatkan pemahaman mahasiswa sebagai calon guru dalam mendesain film pembelajaran sekaligus praktik langsung pembuatan media pembelajaran sehingga mampu mengatasi 
segala kelemahan dan keterbatasan yang ada.

Berdasarkan latar belakang di atas, maka penulis mengajukan beberapa rumusan masalah sebagai berikut a ). Bagaimana proses penyusunan naskah film pembelajaran oleh mahasiswa Fisika? dan b ). Bagaimana sebaran tingkat kemampuan mahasiswa dalam proses penyusunan naskah dan editing film pembelajaran berdasarkan analisa hasil produk film?

\section{METODE PENELITIAN}

Metode yang digunakan dalam penelitian ini adalah dengan menggunakan pendekatan kuantitatif deskriptif. Penelitian ini dilakukan di Fakultas Ilmu Tarbiyah dan keguruan UIN Walisongo terhadap mahasiswa TF - 4A pendidikan Fisika semester genap tahun 2014-2015. Penelitian ini di ruang perkuliahan yang terjadwal dan di laboratorium Fisika Dasar Selama 4 bulan.

\section{Teknik Pengumpulan Data}

Teknik pengumpulan data Pelaksanaan ini penelitian ini adalah :

1. Proses pengambilan data ini terbagi menjadi 3 proses :

a. Pembuatan naskah film pembelajaran

Pada proses ini mahasiswa dibimbing bagaimana membuat desain pembelajaran runtutan tahap demi tahap dalam slide film pembelajaran dari covering, isi, dan penutup yang meliputi dua jenis yaitu narasi dan visualisasi yang harus seiring dan sejalan

b. Capture dan Editing

Setelah penyusunan naskah film selesai dan revisi dari dosen maka mahasiswa selanjutnya mengambil gambar, video sesuai dengan tahap demi tahap dari naskah yang dibuat dan juga sesuai dengan kreasi dari mahasiswa. Tahap inilah yang memerlukan kreativitas tinggi yang menentukan tampilan film pembelajaran. Setelah semua gambar dan video telah terkumpul maka langkah selanjutnya mahasiswa mengedit dengan software editing film ( movie maker, ulead) maupun yang lain sesuai dengan tingkah kemampuan mahasiswa

c. Rendering

Ketika semua file telah di edit dengan software video/film maka film siap di render supaya menjadi satu kesatuan yang utuh dan ditampilkan dengan format 
film tertentu supaya bisa di simpat dalam CD/DVD maupun hanya sebagai file film ( DAT, flv, mp3, maupun lainnya)

\section{Populasi dan sampel}

Populasi dan Sampel yang digunakan dalam penelitian ini adalah kelas TF-4A mahasiswa pendidikan Fisika angkatan 2013.

\section{Desain Film}

Pembuatan Film adalah pembuatan skenario gambar bergerak. Pada setiap proses sangat penting tetapi yang lebih penting pada keberhasilan film pembelajaran adalah proses pembuatan naskah Film. Naskah film adalah bagian yang menentukan akan runtutan pembelajaran yang akan ditayangkan, kesesuaian antara materi dengan film yang akan di produksi. Tahap-tahapan pembuatan Film :

1. Pembuatan naskah Film

Pembuatan naskah film pembelajaran ini merupakan bagian yang terpenting dalam desain film pembelajaran. Naskah film terbagi menjadi dua bagian yaitu visualisai dan narasi, kedua komponen ini harus sesuai.

2. Editing Film

Edit film ini terbagi dalam tiga bagian yaitu capture video dan gambar, pengambilan suara dan rendering. Keberhasilan proses editing film ini akan memberi kontribusi terhadap kualitas produk film baik mengenai gambar, suara, dan kesesuaian antara gambar dan suara.

Film ini di rancang dan di desain hanya untuk pembelajaran praktikum Fisika Dasar.

\section{Instrumen Penelitian}

\section{a. Lembar Penilaian}

Lembar penilaian yang digunakan yaitu penilaian penilaian produk. Pada proses pembuatan naskah film akan terlihat pada hasil produknya sehingga instrumen penilaian hasil meliputi runtutan alur cerita, kesesuaian dengan materi, gambar, volume, pemilihan warna, dan kesesuaian audio dengan video. Proses penyusunan naskah film yang tervisualisasi dengan hasil sehingga hasil produknya menggunakan menggunakan lembar observasi dengan pendekatan rating scale. 
Edi Daenuri Anwar/ Phenomenon Vol. 08, No.1, Juli 2018

Hasil observasi akan di kuantisasi dan didiskripsikan dengan pendekatan deskriptif sehingga akan menggambarkan sebaran kemampuan mahasiswa fisika sebagai calon guru dalam kemampuan memproduksi film pembelajaran fisika.

Tabel 1 Instrumen Penilaian

\begin{tabular}{|c|c|c|c|c|c|c|}
\hline $\mathrm{NO}$ & Komponen Analisa & 1 & 2 & 3 & 4 & 5 \\
\hline & A. MATERI & & & & & \\
\hline 1 & $\begin{array}{l}\text { Sesuai dengan tujuan yang telah } \\
\text { dirumuskan }\end{array}$ & & & & & \\
\hline 2 & Mudah difahami & & & & & \\
\hline 3 & $\begin{array}{l}\text { Sesuai dengan tingkat } \\
\text { kemampuan pengguna / } \\
\text { Mahasiswa }\end{array}$ & & & & & \\
\hline 4 & $\begin{array}{l}\text { Bahan disajikan dari sederhana } \\
\text { menuju ke kompleks }\end{array}$ & & & & & \\
\hline 5 & Bahan disajikan runtut dan teratur & & & & & \\
\hline & B. NARASI & & & & & \\
\hline 6 & Volume suara sangat baik & & & & & \\
\hline 7 & $\begin{array}{l}\text { Intonasi suara memudahkan } \\
\text { pemahaman }\end{array}$ & & & & & \\
\hline 8 & $\begin{array}{l}\text { Gaya bahasa yang di gunakan } \\
\text { sangat jelas }\end{array}$ & & & & & \\
\hline 9 & $\begin{array}{l}\text { Ucapan memiliki kejelasan yang } \\
\text { baik }\end{array}$ & & & & & \\
\hline 10 & $\begin{array}{l}\text { Bahasa yang di gunakan } \\
\text { sederhana dan mudah di pahami }\end{array}$ & & & & & \\
\hline & C. MUSIK/EFEK SUARA & & & & & \\
\hline 11 & $\begin{array}{l}\text { Ilustrasi musik/ background } \\
\text { mendukung program }\end{array}$ & & & & & \\
\hline 12 & $\begin{array}{l}\text { Ilustrasi musik dan efek suara } \\
\text { tidak terlalu mengganggu }\end{array}$ & & & & & \\
\hline
\end{tabular}

Keterangan :

Skor 5 : Sangat baik/ Sangat Sesuai

Skor 4 : Baik/ Bagus/ Sesuai

Skor 3 : Cukup

Skor 2 : Kurang baik/ Jelek

Skor 1 : Sangat Jelek/ Sangat Kurang 


\section{Teknik Analisis Data}

Edi Daenuri Anwar/ Phenomenon Vol. 08, No.1, Juli 2018

Analisa data yang dilakukan untuk mengolah data yang diperoleh dilapangan sehingga diperoleh data yang mencakup semua jawaban dari permasalahan yang dirumuskan. Kemampuan mahasiswa pendidikan Fisika yang menjadi populasi dalam mendesain film pembelajaran yang dilakukan dalam penelitian ini ke dalam data numerik terhadap aspek-aspek yang dinilai dari film yang telah didesain mahasiswa. Analisa data ini meliputi materi, narasi dan musik untuk instrumen pengguna, sedangkan instrumen untuk ahli/dosen meliputi materi, narasi, musik dan visualisasi.

Tabel 2 Kriteria penilaian Ideal

\begin{tabular}{|l|l|l|}
\hline No & Rentang Skor & Kategori \\
\hline 1 & $\mathrm{X}>\mathrm{Mi}+1,5 \mathrm{Sbi}$ & Sangat baik \\
\hline 2 & $\mathrm{Mi}+0,5 \mathrm{Sbi}<\mathrm{X} \leq \mathrm{Mi}+1,5 \mathrm{Sbi}$ & Baik \\
\hline 3 & $\mathrm{Mi}-0,5 \mathrm{Sbi}<\mathrm{X} \leq \mathrm{Mi}+1,5 \mathrm{Sbi}$ & Cukup \\
\hline 4 & $\mathrm{Mi}-0,5 \mathrm{Sbi}<\mathrm{X} \leq \mathrm{Mi}-1,5 \mathrm{Sbi}$ & Kurang \\
\hline 5 & $\mathrm{X} \leq \mathrm{Mi}-1,5 \mathrm{Sbi}$ & Sangat kurang \\
\hline
\end{tabular}

(Sudijono, 1987)

Keterangan :

X : skor rata-rat

Mi : Rata-rata Ideal

Sbi : Simpangan baku

Skor maksimal ideal $=\Sigma$ butir $\mathrm{x}$ skor tertinggi

Skor minimal ideal $=\Sigma$ butir $\mathrm{x}$ skor terendah

$$
\text { skor penilaian }=\frac{\text { jumlah skor }}{\text { skor maksimal }} \times 100 \%
$$

Hasil persentase kriteria penilaian dapat di lihat pada tabel berikut :

Tabel 3 kategori persentase penilaian

\begin{tabular}{|c|c|}
\hline Rata- nilai kelas & Kategori \\
\hline $80 \%<\mathrm{x} \leq 100 \%$ & Sangat baik \\
$67 \%<\mathrm{x} \leq 80 \%$ & Baik \\
$53 \%<\mathrm{x} \leq 67 \%$ & Cukup \\
$40 \%<\mathrm{x} \leq 53 \%$ & Jelek \\
$\mathrm{x}<40 \%$ & Sangat jelek \\
\hline
\end{tabular}

Tabel 4 Kriteria penilaian ideal penskoring rata setiap komponen

\begin{tabular}{|c|c|}
\hline Rata- nilai kelas & Kategori \\
\hline $\mathrm{X}>4,005$ & Sangat baik \\
$3,335<\mathrm{x} \leq 4,005$ & Baik \\
$2,665<\mathrm{x} \leq 3,335$ & Cukup \\
$1,995<\mathrm{x} \leq 2,665$ & Kurang \\
$\mathrm{x} \leq 1,995$ & Sangat kurang \\
\hline
\end{tabular}




\section{HASIL DAN PEMBAHASAN}

Edi Daenuri Anwar/ Phenomenon Vol. 08, No.1, Juli 2018

\section{Analisa konten materi kesesuaian dengan materi yang telah di rumuskan}

Produk yang terdiri dari sebelas film berdasarkan penilaian dari pengguna menunjukkan bahwa nilainya sesuai dengan grafik dibawah ini. 64\% menilai bahwa film yang dibuat memiliki kategori baik menurut penilain dari pengguna.

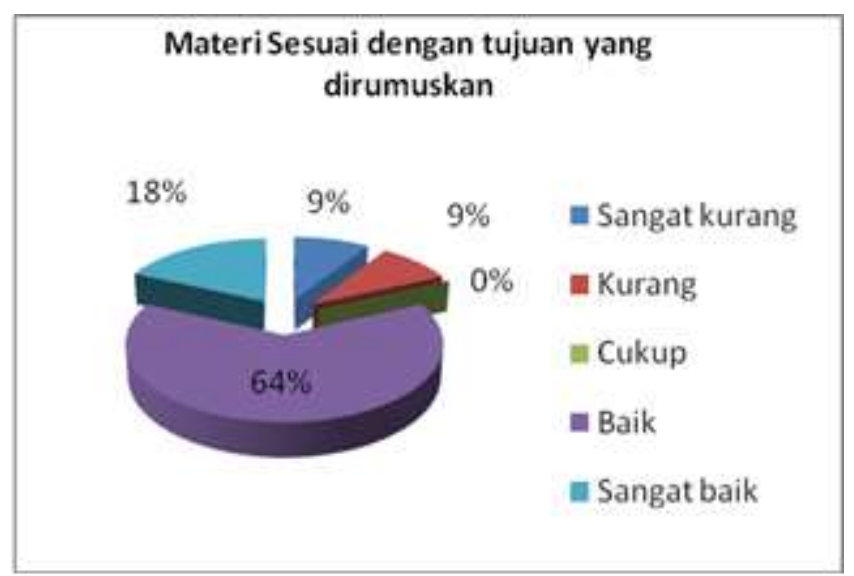

Gambar 1 : Grafik kesesuaian materi dengan tujuan yang dirumuskan

Hasil penilaian dari pengguna kemudian dianalisis menunjukkan bahwa secara keseluruhan materi sesuai dengan tujuan yang dirumuskan memperoleh nilai rata-rata 3,77 menunjukkan baik dan prosentase $75 \%$ menunjukkan baik.

\section{b. Analisa konten materi mudah difahami}

Berdasarkan penilaian dari pengguna menunjukkan bahwa nilainya sesuai dengan grafik dibawah ini. $46 \%$ menilai bahwa film yang dibuat dalam kategori kemudahan memahami materi memiliki kategori baik menurut penilain dari pengguna. Sedangkan yang lainnya sesuai dengan gambar 2 .

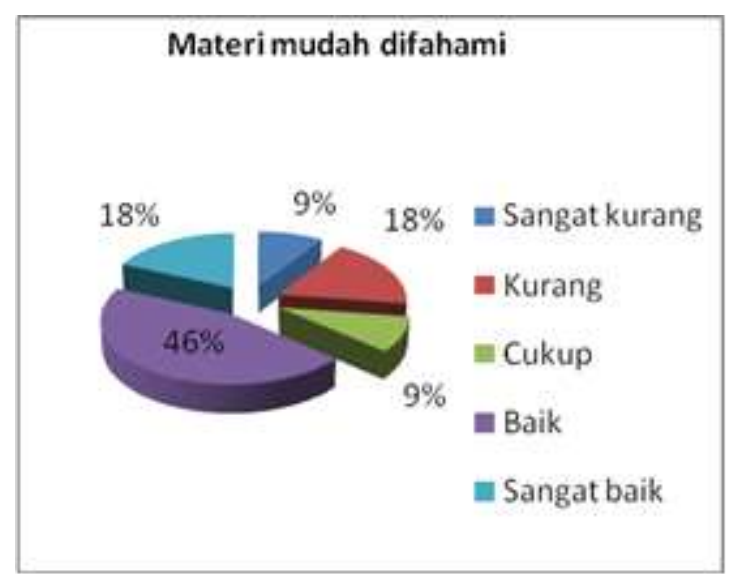

Gambar 2: Grafik kemudahan memahami materi 
Edi Daenuri Anwar/ Phenomenon Vol. 08, No.1, Juli 2018

Hasil data yang di dapat kemudian di analisis mengenai kemudahan memahami materi menunjukkan bahwa nilai rata-rata 3,45 yang memberikan indikasi bahwa indikator ini baik sedangkan prosentasenya $69 \%$ yang berdasarkan penilaian ideal pada keadaan yang baik.

\section{c. Analisa konten materi sesuai dengan tingkat kemampuan pengguna/}

\section{Mahasiswa}

Berdasarkan penilaian dari pengguna menunjukkan bahwa materi sesuai dengan tingkat kemampuan pengguna / mahasiswa menunjukkan bahwa 46\% menilai bahwa film yang dalam kategori baik, sedangkan $18 \%$ kurang dan sangat baik. Sedangkan yang lainnya sesuai dengan gambar 3.

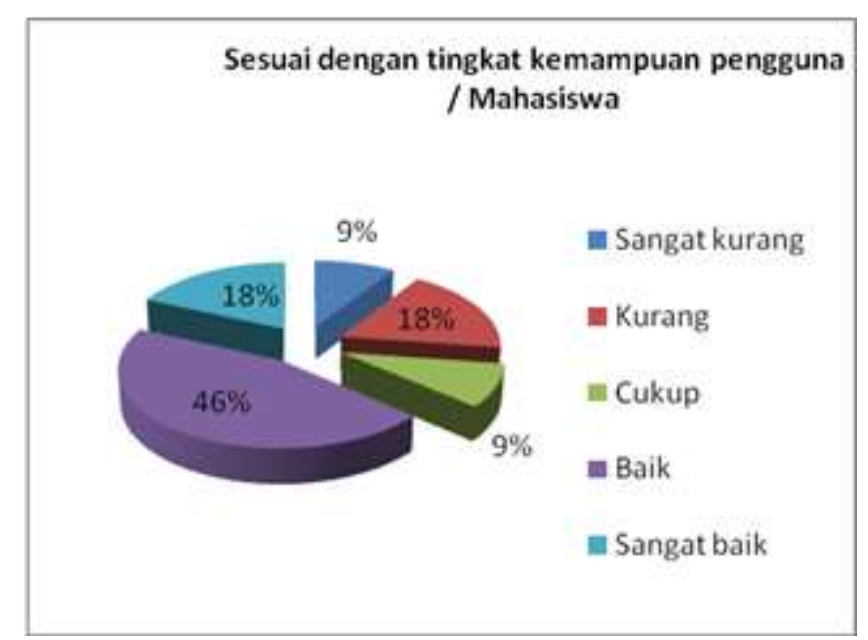

Gambar 3 : Grafik kesesuain dengan tingkat kemampuan pengguna/mahasiswa.

Data yang di dapat dianalisa menunjukkan bahwa nilai rata-rata 3,54 sehingga dalam kategori baik dan prosentase $71 \%$ juga menunjukkan analisis yang baik.

\section{d. Analisa konten materi bahan disajikan dari sederhana menuju ke kompleks}

Berdasarkan penilaian dari pengguna menunjukkan bahwa materi bahan disajikan dari sederhana menuju ke kompleks menunjukkan bahwa $64 \%$ menilai bahwa film yang dalam kategori baik, sedangkan 18\% sangat kurang, $9 \%$ kurang dan $9 \%$ cukup. Sesuai dengan gambar 4. 


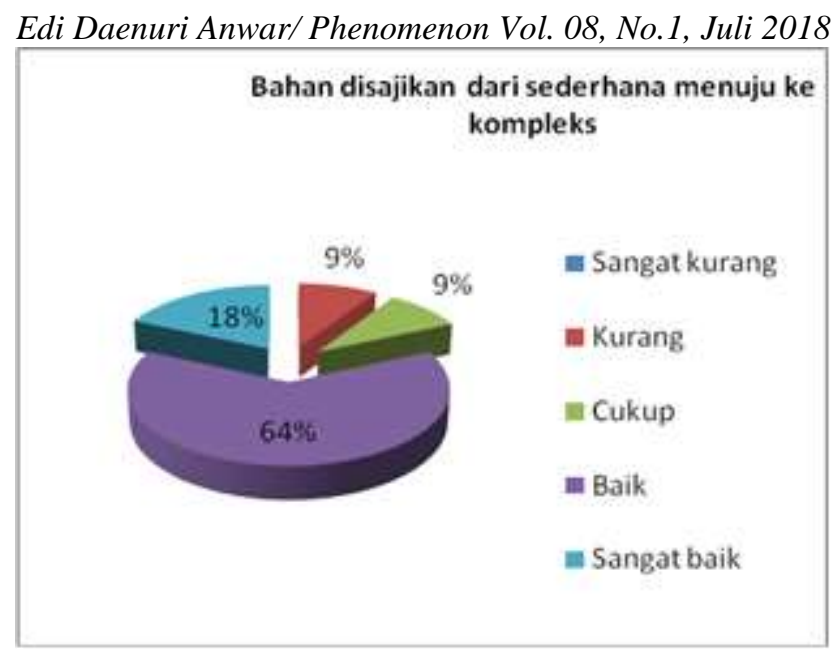

Gambar 4 : Grafik bahan disajikan dari sederhana menuju ke kompleks

Data hasil kemudian dianalisis menunjukkan bahwa nilai rata-rata 3,9 menunjukkan kategori baik dan prosentase $78 \%$ juga menunjukkan penilaian yang baik.

\section{e. Analisa konten materi bahan yang disampaikan runtut dan teratur}

Berdasarkan penilaian dari pengguna menunjukkan bahwa materi bahan disajikan runtut dan teratur menunjukkan bahwa 64\% baik, 9\% sangat kurang, dan 27 $\%$ kurang. Sesuai dengan gambar 5.

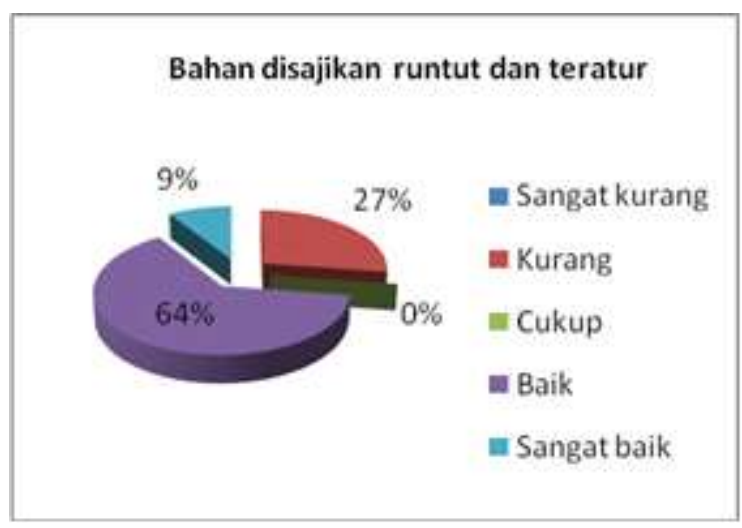

Gambar 5 : Grafik konten materi bahan yang disampaikan runtut dan teratur

Sedangkan hasil analisis dari data yang diperoleh menunjukkan hasil bahwa rata - rata nilai 3,54 menunjukkan nilai baik dan menunjukkan bahwa hasil secara keseluruhan menunjukkan prosentase $71 \%$. Sehingga dapat di katakan bahwa komponen ini juga menunjukkan hasil yang baik. 


\section{f. Analisa narasi volume suara}

Edi Daenuri Anwar/ Phenomenon Vol. 08, No.1, Juli 2018

Berdasarkan penilaian dari pengguna menunjukkan bahwa narasi volume sangat baik menunjukkan bahwa $37 \%$ baik, 9\% sangat baik, dan $18 \%$ sangat kurang, $27 \%$ kurang dan $9 \%$ cukuop. Sesuai dengan gambar 6.

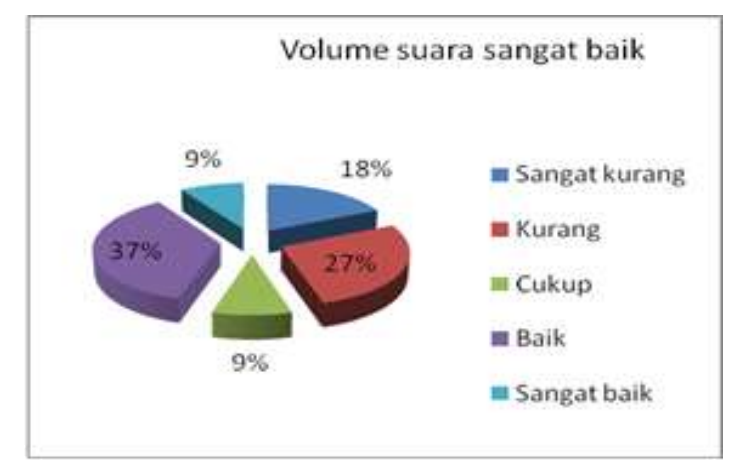

Gambar 6 : Grafik narasi volume suara

Sedangkan hasil analisis menunjukkan bahwa pada indikator tersebut memperoleh nilai rata-rata 2,9 sehingga indikatornya cukup. Pada komponen ini perlu adanya perbaikan dan peningkatan. Sedangkan prosentase menunjukkan 58\% sehingga memberikan indikasi cukup.

Dari analisis yang diperoleh sehingga menunjukkan bahwa komponen penilaian mengenai narasi pada volume suara perlu ada perbaikan dan peningkatan sehingga film yang telah menjadi produk bisa bermanfaat kepada sebanyak-banyaknya pengguna yang lain.

\section{g. Analisa konten Intonasi suara untuk memudahkan pemahaman}

Berdasarkan penilaian dari pengguna menunjukkan bahwa intonasi suara yang memudahkan pemahaman menunjukkan bahwa 64\% baik, 9\% sangat baik, dan $9 \%$ sangat kurang, dan $18 \%$ cukup. Sesuai dengan gambar 7.

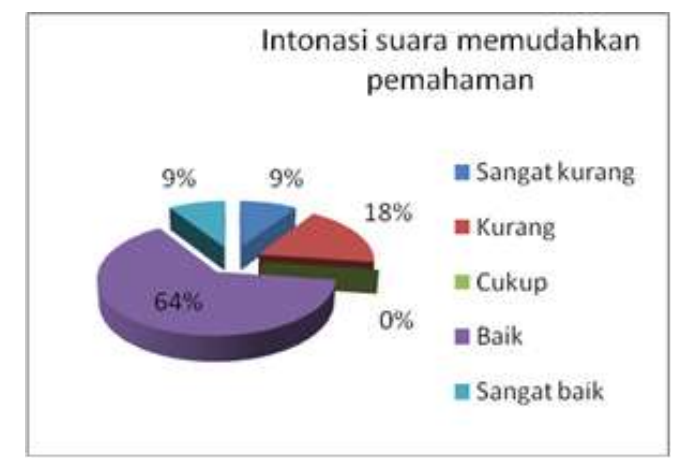

Gambar 7 : Grafik intonasi suara untuk memudahkan pemahaman 
Edi Daenuri Anwar/ Phenomenon Vol. 08, No.1, Juli 2018

Sedangkan hasil analisis menunjukkan bahwa nilai rata-rata nilai 3,45 sehingga menunjukkan bahwa film yang telah didesain secara umum dalam kategori baik dan prosentase $69 \%$ juga baik.

\section{h. Analisa gaya bahasa yang digunakan sangat jelas}

Berdasarkan penilaian dari pengguna menunjukkan bahwa Gaya bahasa yang digunakan sangat jelas menunjukkan bahwa 55\% baik, $0 \%$ sangat baik, dan $9 \%$ sangat kurang, $18 \%$ cukup dan $18 \%$ cukup. Sesuai dengan gambar 8.

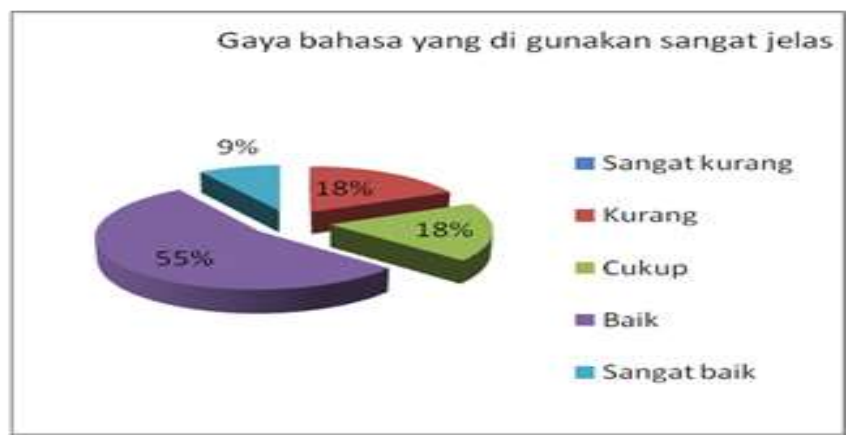

Gambar 8 : Grafik kejelasan penggunaan bahasa

Sedangkan hasil analisis memperoleh rata nilai rata-rata 3,54 memberikan indikator baik baik dan prosentase $71 \%$. Juga menunjukkan indikator yang baik.

\section{h. Analisa Ucapan memiliki kejelasan yang baik}

Berdasarkan penilaian dari pengguna menunjukkan bahwa $46 \%$ baik, 9\% cukup, 36 kurang sangat baik, dan $9 \%$ sangat kurang, 9\% sangat kurang sedangkan 0\% sangat kurang. Sesuai dengan gambar 9.

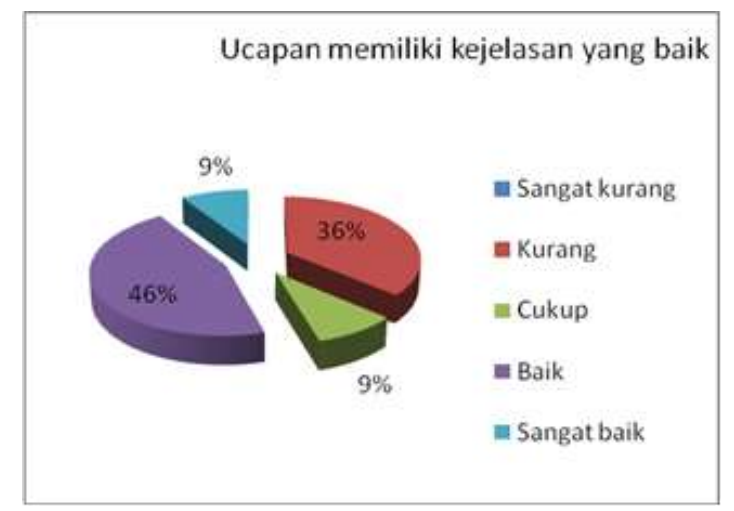

Gambar 9 : Grafik kejelasan Ucapan 
Edi Daenuri Anwar/ Phenomenon Vol. 08, No.1, Juli 2018

Sedangkan Analisa hasil menunjukkan nilai rata-rata 3,27 sehingga dalam kategori cukup, komponen penilaian mengenai kejelasan ucapan perlu adanya editing dan peningkatan sehingga bisa lebih baik sedangkan prosentase $65 \%$ juga memberikan penilaian cukup.

\section{i. Analisa Bahasa yang digunakan sederhana dan mudah difahami}

Berdasarkan penilaian dari pengguna menunjukkan bahwa $55 \%$ baik, $18 \%$ cukup, $18 \%$ kurang, dan $9 \%$ sangat kurang, dan 9\% sangat. Sesuai dengan gambar 10.

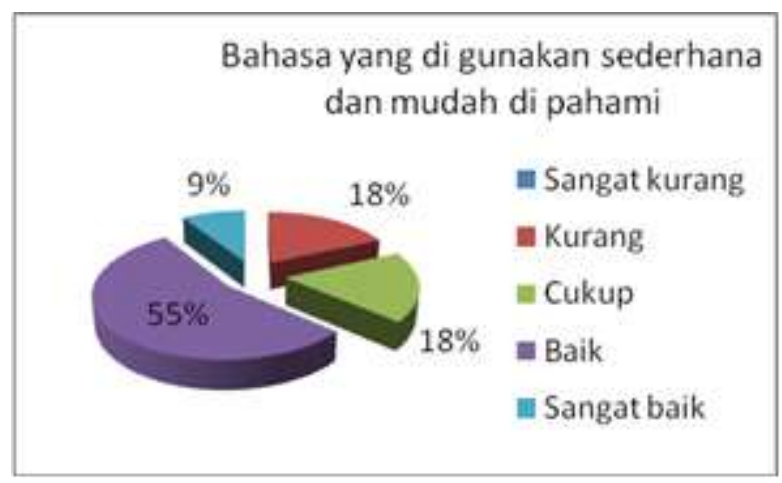

Gambar 10 : Grafik tingkat penggunaan Bahasa dari sederhana dan mudah difahami

Sedangkan Analisa hasil menunjukkan nilai rata-rata memperoleh nilai 3,54 jika berdasar pada penilaian ideal nilai rata-rata menunjukkan bahwa komponen ini memiliki tingkat penilaian yang baik sedangkan prosentase $71 \%$ juga termasuk dalam kategori baik.

\section{j. Analisa ilustrasi musik mendukung program}

Berdasarkan penilaian dari pengguna menunjukkan bahwa $27 \%$ baik, $9 \%$ cukup, 37\% kurang, $9 \%$ sangat kurang, dan 18\% sangat baik. Sesuai dengan gambar 11.

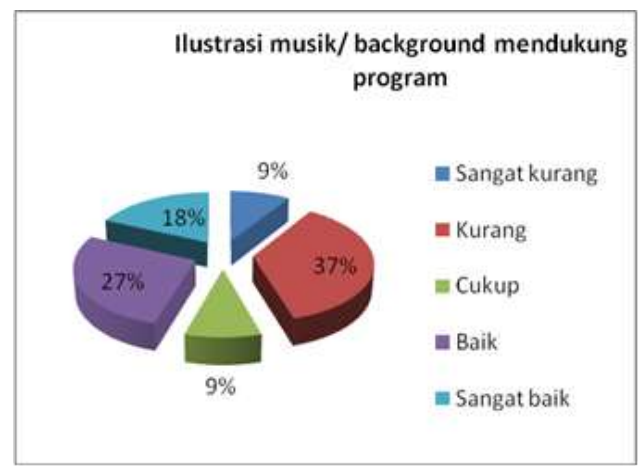

Gambar 11 : Grafik ilustrasi musik mendukung program 
Edi Daenuri Anwar/ Phenomenon Vol. 08, No.1, Juli 2018

Sedangkan Analisa hasil menunjukkan nilai rata-rata memperoleh nilai rata-rata 3,09 sehingga menurut indikator penilaian termasuk cukup, sehingga aspek ini perlu ditambah dan ditingkatkan sedangkan prosentase $62 \%$ termasuk juga dalam kategori cukup sehingga pada komponen penilaian ini perlu adanya peningkatan dan revisi. Demikian juga perlu adanya pemilihan musik sesuai background sehingga tidak mengganggu suara asli/Pokoknya

\section{h. Analisa ilustrasi musik dan efek suara tidak terlalu mengganggu.}

Berdasarkan penilaian dari pengguna menunjukkan bahwa 55\% baik, $0 \%$ cukup, 27\% kurang, $9 \%$ sangat kurang, dan 9\% sangat baik. Sesuai dengan gambar 12.

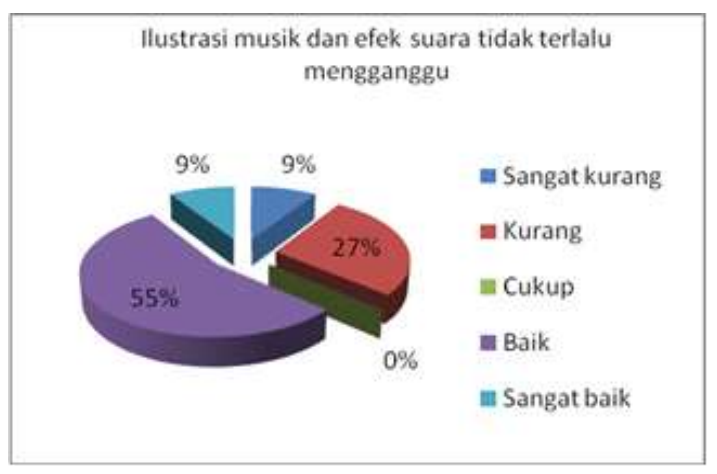

Gambar 12 : Grafik ilustrasi musik dan efek suara

Sedangkan analisa hasil menunjukkan nilai rata-rata memperoleh nilai 3,2 sehingga untuk komponen ini tergolong cukup sehingga perlu di tingkatkan dan prosentase 65\% tergolong cukup. Analisa ini memberikan gambaran bahwa dalam penyusunan pemilihan desain musik dan ilustrasi musik dan efeknya diperhatikan semua sebaik mungkin sehingga tidak menggannggu.

\section{SIMPULAN DAN SARAN}

Dalam pendesainan film pembelajaran yang dilakukan mahasiswa Pendidikan Fisika pada matakuliah media pembelajaran tahun pelajaran 2014/2015 dimulai dengan pembuatan naskah film setelah naskah di buat mahasiswa membuat serangkaian film yang merupakah hasil dari naskah film. Film ini tentang praktikum fisika Dasar Produk dari film pembelajaran yang telah di buat oleh mahasiswa di uji dengan oleh mahasiswa pengguna dan dosen sebagai pakar /Ahli media. 
Edi Daenuri Anwar/ Phenomenon Vol. 08, No.1, Juli 2018

Hasil penilaian oleh pengguna meliputi materi, suara, musik dan visualisasi. Dari hasil penilaian oleh mahasiswa dan dosen diolah dengan pendekatan kuantitatif dan didiskripsikan berdasarkan hasil pengolahan kuantitatif tersebut. Hasilnya menunjukkan bahwa secara umum materi yang terdiri dari a) Kesesuaian materi dengan tujuan yang dirumuskan, b) materi mudah difahami, c) materi sesuai dengan tingkat kemampuan pengguna/ Mahasiswa, d) bahan disajikan dari sederhana menuju ke kompleks, dan e) bahan yang disampaikan runtut dan teratur. Kelima komponen yang dari pengguna menyatakan baik. Sedangkan unsur kedua narasi yang meliputi a) volume suara, b) intonasi suara untuk memudahkan pemahaman, c) gaya bahasa yang digunakan sangat jelas, d) kejelasan ucapan dan e) bahasa yang digunakan sederhana dan mudah difahami. Secara umum baik kecuali pada komponen d) kejelasan ucapan yang memberikan penilain cukup. dan Komponen penilaian ketiga yaitu musik yang terdiri dari a) ilustrasi musik mendukung program dan b) ilustrasi musik dan efek suara tidak terlalu mengganggu, kedua unsur ini dalam kategori cukup.

Sedangkan penilaian dari dosen atau tim ahli meliputi materi, narasi, musik dan visualisasi. Materi terdiri dari a) konten sesuai dengan tujuan yang telah dirumuskan, b) kelengkapan konten materi praktikum, c) keruntutan dan keteraturan bahan sajian, ketiga komponen dalam kategori cukup. Sedangkan narasi meliputi a) diksi yang digunakan, b) kejelasan pengucapan c) Bahasa yang digunakan sederhana dan mudah difahami, ketiga komponen narasi menyatakan cukup. kemudian penilaian yang ketiga yaitu musik (Ilustrasi musik/ background cocok dengan judul ) dalam kategori cukup. Sedangkan penilaian yang keempat yaitu visualisasi (improvisasi visual) juga dalam kategori cukup. 


\section{DAFTAR RUJUKAN}

Edi Daenuri Anwar/ Phenomenon Vol. 08, No.1, Juli 2018

Ali, M, Dkk. 2005. "Pengembangan Bahan Pembelajaran Berbantuan Komputer Untuk Memfasilitasi Belajar Mandiri Dalam Mata Diklat Penerapan Konsep Dasar Listrik Dan Elektronika Di SMK'.Laporan Penelitian Research Grant PHK A2 Jurusan Pendidikan Teknik Elektro FT UNY

Arsini, 2011, Modul Praktikum Fisika I, Laboratorium Fisika Fakultas Tarbiyah IAIN Walisongo Semarang

Arsyad, Azhar. 1997,Media Pembelajaran, PT Raja Grafindo Persada, Jakarta

Asnawir dkk. 2002, Media pembelajaran. Jakarta: Ciputat Press. Jakarta

Harms, Virtual and Remote Labs in Physics Education, German Institut for Research on Distance Education in the University of Tuebingen, 1

Sugiyono. 2009. Metode Penelitian Pendidikan : Pendekatan Kuantitatif, Kualitatsif dan $R \& D$. Bandung : Penerbit Alfabet

Sullivan, Karen, Schumer, Gary, Alexander, Kate, 2008, Ideas for the Animated Short, Oxford: Elsevier Inc

Syaiful Bahri Djamarah, Guru dan Anak Didik dalam Interaksi Edukatif, cet. 1, Jakarta Rineka Cipta, 2000.

Wenti, 2009. Pengembangan Pengajaran Praktik dengan Pre-Lab berbasis Simulatiuon Software, Laporan Hasil Penelitian DIPA IAIN Walisongo Semarang 